\title{
China's Iron and Steel Industry at the Global Markets Interface: Structural Developments and Industrial Policy Interventions
}

\author{
PETER IN DER HEIDEN AND MARKUS TAUBE
}

\begin{abstract}
In recent years the Chinese iron and steel industry has gone through a period of hyper growth, propelling it to the very top of global steel-making. Commanding nearly half of global output and correspondingly utilizing a similar share of inputs and raw materials, China has become the key player in this industry, exerting significant influence on global prices and cost parameters. But just as the rise of China's iron and steel industry was not only driven by market forces but heavily influenced by government intervention in commodity and financial markets, government authorities are also trying to exert influence on the way Chinese steel-makers are acting on the global markets. Balancing market forces and industrial policy strategy at the global markets interface, political decision-makers have worked out an elaborate framework of measures to carve out maximum benefits for domestic enterprises and the economy as a whole. By examining these mechanisms, this article aims to illustrate that sectoral industrial policy in China does not push for expanding exports and investments across the board but carefully and discretionarily promotes global integration in some areas while delaying it in others.
\end{abstract}

Keywords: China, steel industry, industrial policy, trade policy, foreign direct investment

\section{Introduction}

Since the founding of the People's Republic of China, consecutive leadership generations have attributed great importance to the steel industry, considering a large steel sector as a basic precondition for successful national development. But after an attempt to rapidly increase steel output during the 'Great Leap Forward' campaign spectacularly backfired, very slow progress was made before the onset of economic reforms. Since then, Chinese steel-making has greatly improved its structural 
and technological set-up and witnessed an unprecedented rise after the early 1990s. Driven by nationwide urbanization and industrialization trends, output volumes skyrocketed, without falling back even during three global financial crises. After surpassing Japan as the world's leading steel producer in 1996, volumes have continued to expand so that since 2009 almost half of global steel output took place in China (WSA various years). ${ }^{1}$ Having reached 627 million tons of crude steel output in 2010, the Ministry for Industry and Information Technology (MIIT) predicts crude steel output to exceed 700 million tons in 2011 (MIIT 2010, 2011), with another 100 million tons of production capacity being installed.

These developments have gone along with China's rise as a major importer and exporter of both steel products and relevant raw materials. Before the recent global economic downturn, the country was on a long-term trajectory of export growth. In 2006, China became the world's leading steel exporter but lost the title to Japan again in $2009 .{ }^{2}$ In the meantime, Chinese enterprises held a cumulative world market share of 12 to 15 per cent. ${ }^{3}$ However, while exports are an important aspect for some Chinese mills, their share in domestic steel production has never topped 12 per cent, which is a fairly low percentage compared to other major steel-producing nations (WSA 2010). ${ }^{4}$ Interestingly, there is a huge discrepancy in the composition of China's imports and exports. While imports are still made up of technology-intensive wares, like electrical steel or galvanized sheet, exports mostly consist of mediumgrade products, such as hot rolled sheet or section steel. While it has to be conceded that Baosteel and a handful of other leading steel-makers have expanded exports of high-grade materials, for example, coated, plated or clad sheets, in recent years, differences continue to exist between incoming and outgoing goods in terms of technical specifications and quality levels nevertheless. Correspondingly, the average cost per ton of imports and exports was US\$1,181 and US\$792 respectively for the first half of 2010 (CISA 2010).

In recognition of the potential influence of the steel industry, the Chinese government is dedicating substantial resources to the monitoring and micro-management of China's steel industry in general and its interaction with the global markets in particular. Balancing market forces and industrial policy strategy, political decision-makers have worked out an elaborate framework of measures to create an environment conducive to the development of this industry. As such, the steel industry is subjected to numerous policy measures steering its development in both the do- 
mestic and international context (Taube \& in der Heiden 2009, 2010). By examining those mechanisms addressing the global markets interface, this article aims to illustrate that sectoral industrial policy in China does not push for expanding exports and investments across the board, but carefully and discretionarily promotes global integration in some areas while delaying it in others. Sections two and three will discuss how government regulations have shaped the global integration of China's steel enterprises, with section two focusing on trade, that is, Chinese exports and imports of raw materials and (semi) finished products, and section three targeting inward and outward directed investment issues. The article concludes with a summary of findings in section four.

\section{China's Trade in Iron and Steel Industry-Related Products: Patterns and Policies}

With regard to foreign trade, government policy heavily emphasizes the concept of 'two markets and two resources' as a source of advantage (e.g., NDRC 2005; MIIT 2009). Companies are asked to seize opportunities from leveraging procurement and sales both on the home market and abroad. In the following, we will take a detailed look at the way this is done and how Chinese policy-makers are trying to influence and structure steel-related import and export activities.

\section{Imports of Raw Materials}

Iron ore is the most important raw material for steel-making. In 2009, 92 per cent of Chinese and 70 per cent of global steel production was based on smelting the mineral (WSA 2010). China possesses the world's fourth largest iron ore deposits and is the largest miner of the mineral, producing 900 million tons - equivalent to 39 per cent ${ }^{5}$ of world output in 2009 (USGS 2010). The unabated steep rise in crude steel output over the past 20 years has driven China's mining industry to continuously expand operations, thereby vastly increasing the supply of domestic iron ore. However, while this process is still well underway, new mining projects have gradually become more demanding both technically and financially as remaining deposits get increasingly difficult to exploit. With domestic miners burdened by rising production costs and limited growth potential, Chinese steel-makers faced with escalating shortages and rising prices have long turned to the world market for their iron ore needs. Adding to the list of superlatives, China became the world's largest iron ore importer in 2003 and has kept the title ever since (Yu \& 
Yang 2010). By 2009, Chinese imports accounted for about two-thirds of the total internationally traded iron ore, both in terms of volume and value (United Nations Statistics Division 2010; WSA 2010). At the same time, the country depended on international deliveries for 69 per cent or 630 million tons of the iron ore processed in its furnaces. ${ }^{6}$ Due to the unrivalled dimensions of Chinese iron ore imports, world markets bore witness to dramatic increases in trade volumes ${ }^{7}$ and price levels. ${ }^{8}$ To ease the pressure on its steel mills, the Chinese government and the China Iron and Steel Association (CISA) in particular have launched a whole range of initiatives designed to create a Chinese buyers cartel and increase the negotiation power of Chinese enterprises vis-à-vis international iron ore miners and shipping lines (CISA 2009b).

Government authorities have blamed the large number of iron ore importers and the subsequently low degree of coordination for unnecessarily inflating import demand and driving up market prices (CISA 2009b). To tackle this structural problem, a series of measures for streamlining iron ore import operations has been introduced. In a first move, in 2005, a coalition of government agencies and CISA compiled a catalogue of requirements Chinese enterprises would have to meet in order to qualify as iron ore importers. Based on this catalogue, a list of approved importers has been put together while all other enterprises were effectively barred from iron ore import transactions. Since then, the original number of more than 500 qualified importers has been gradually cut to 112 companies - 70 of which are steel-makers - in 2009 (Hexun. com 2010). This import cartel stands to become even more exclusive since new standards introduced in early 2010 are intended to further reduce the number of enterprises. In order to maintain its import license, a company now needs to prove ore imports in excess of 1 million tons in 2009 (CISA \& CCCMC 2010).

Tasked with supervising iron ore imports by central government authorities, CISA is in charge of several initiatives to consolidate and regulate iron ore import activities. In February 2009, the association launched a 'Convention for Enhancing Self-discipline in the Iron and Steel Industry to Ensure an Orderly Iron Ore Import Trade', stipulating that the whole of the industry be represented by a designated group of negotiators at the international iron ore price talks and mandating that the resulting price agreement be binding for all Chinese importers (CISA 2009a). This effectively forbids other interested parties from engaging in their own price negotiations and striking a separate deal. Furthermore, the small number of steel-makers approved for ore imports may not pur- 
chase amounts in excess of their own consumption needs. Medium-sized enterprises and those importing less than one million tons per year are put at a disadvantage because they have to procure imported materials through an agency system, forcing them to accept service surcharges of 3 to 5 per cent. The large number of smaller players that are due to lose their production license based on a host of industrial policy guidelines of recent years are cut off from the supply of imported materials completely (CISA 2009a). This system is complemented by a barrage of monitoring, control and supervision mechanisms that are intended to stall any kind of circumvention attempt. While the system is tilted in favour of the relatively small group of large, integrated state-owned enterprises and clearly discriminates against smaller players, it mostly aims to limit overall import volumes and strengthen China's bargaining power in price negotiations (CISA 2009a). It can be argued that in both regards, it has a potentially significant effect on market outcomes for global iron ore trade. For the lack of a counterfactual, however, it is difficult to assess the extent to which this initiative has actually cut import volumes or impacted prices.

While the idea of pooling demand to increase negotiation power visà-vis suppliers is certainly a strategy that is not in conflict with regular market behaviour, what is striking in the Chinese case is the state-led organization of such an import cartel on the one hand and the obvious neglect of the competitive juxtaposition of steel mills in the specific regions on the other hand. Given a normal market framework and intensive competition, as should be expected in a sector featuring massive overcapacities, the question arises whether individual companies would not rather try to 'go it alone' and derive competitive advantages from better import prices than their local contenders. Especially the larger corporations designated to conduct the negotiations for the whole group could be expected to profit from separated negotiations. Given their size and corresponding import demand, these companies could be expected to negotiate better prices than their local contenders and therefore come into a position to improve their competitive positioning vis-à-vis the latter - up to a stage where they could drive these underperforming companies out of the market and thereby contribute to a much needed consolidation of the industry as a whole. Obviously, in their efforts to improve the 'well-being' of the national steel industry as a whole, China's administrators are still trusting more in their skills to steer developments by discretionary interventions than in the selfregulating power of competitive markets. 


\section{Imports of Finished Products}

Chinese steel imports have traditionally been dominated by high-valued-added goods. This trend has not yet been broken with electrical steel or coated sheets playing a major role (CISA 2010). After its accession to the World Trade Organization (WTO) in 2001, China markedly lowered import tariffs on steel products and largely complied with WTO obligations. Except for repeated calls from government agencies or the government-directed CISA to downstream industries encouraging them to favour domestically produced steel over imports, no significant market intervention can be found. Since steel is regarded as a key ingredient for economic development, governments on various levels have dedicated resources to help domestic steel-makers ramp up production volumes, improve quality levels and bring down costs for inputs and utilities. However, it can be argued that assistance in the form of direct subsidies, policy loans, tax benefits or preferential access to vital inputs, energy, water, transportation infrastructure, etc. has contributed to the massive output increases of recent years and thereby greatly diminished import demand (Taube \& in der Heiden 2009). Following this line of reasoning brings up two questions: First, would the Chinese economy have generated the same level of steel demand absent substantial domestic production capacities? And second, would the world market be able to supply enough steel products to accommodate a hypothetical Chinese import dependence similar to that of other major steel producing countries such as the United States? Considering the fact that China's share of global steel consumption has soared for two decades and has almost hit the 50 per cent mark in 2010, the second question would have to be answered with a clear 'no'. In 2009, China consumed a total of 564 million tons of steel, 96 per cent of which was domestically produced (WSA 2010). Based on the 2009 numbers, even a modest rise in import share of a single percentage point would have entailed additional shipments of 5.6 million tons. Bringing the share all the way up to 25 per cent - the level of the United States - would have put China in a position to capture 44 per cent of globally traded steel products (WSA 2010). The latter case would also have put major strain on the global steel market implying momentous distortions of international production and consumption patterns and steep price increases for finished products. While a slightly slower pace of capacity expansion would have avoided the problem of overcapacities, a severely lagging development would have dampened the prospects of China's overall economic development, in turn depressing (import) demand. 


\section{Exports of Raw Materials and Semi-finished Products}

Even after China's WTO accession, government authorities have actively discouraged the export of certain raw materials (such as coke), semifinished products (e.g., billet, slab) and products in the first stages of processing (e.g., hot rolled sheet/coils). Government officials argue that measures to curb outflows of low-value-added materials should serve the conservation of precious natural resources and keep domestic energy consumption, environmental pollution and greenhouse gas emissions in check (GOSC 2010; MIIT 2009). As for the case of coke, these objectives may be well in line with public interest in a country that already suffers from serious environmental damage, energy shortages and heavily relies on burning coal (a major input for the coking process) for electricity generation and heating such as China. ${ }^{9}$

But the whole extent of trade constraints suggests that there are other goals involved as well, notably the creation of a significant price differential for domestic and international consumers of coke and other materials. Bottling up vital inputs for steel-making inside the Chinese market works to increase domestic supply and depress input prices for Chinese steel producers. At the same time, cutting down the export volume reduces the supply of these resources on international markets and thus functions to keep world market prices (and costs of international steel producers) artificially high - in comparison to a free trade, open markets scenario.

Currently, Chinese government authorities are employing five separate mechanisms to either discourage the exportation of certain goods or ensure their outflows come about at very favourable terms for the exporting company and the government budget. These are: (1) export licensing, (2) export quotas, (3) export taxes, (4) cancellation of VAT rebates on exports and (5) export price coordination. In the following, we will give an outline of these restraining mechanisms using the case of coke. ${ }^{10}$

Endowed with large coal deposits, China has evolved to become the world's leading coke producer (USGS 2010). With an output of 353 million tons in 2009, it accounted for 60 per cent of global output in 2009 (China Coal Resource Net 2010). Not surprisingly, the country also used to be the material's largest exporter: before the recent crisis wreaked havoc on global trade, China shipped out 12 million tons in 2007, giving it a market share of 47 per cent in volume terms and 41 per cent in value terms (United Nations Statistics Division 2010; Sun \& Xu 2009). This situation changed dramatically in 2009 when export volumes dropped 
by 96 per cent compared to the previous year (GAC 2010). ${ }^{11}$ Although some part of the collapse can be explained by easing demand, this article argues that primarily export restrictions are to blame.

China-like many other countries-maintains an export licensing system that mostly serves to monitor cross-border trade of commodities and finished products. In theory, the effect of export licensing on trade depends on the degree of intervention and selectivity. In the ideal (free markets) case, licenses will be issued automatically and without any kind of meaningful administrative procedure directly upon shipment since this will cause the least disruption to international trade flows. The worst case from this perspective is a situation where companies are held up by lengthy, costly or arbitrary administrative procedures.

Since China reserves itself the right to restrict or prohibit the export of certain goods it also employs the export licensing scheme as basic supervision and control mechanisms to enforce these trade restrictions. As the agency responsible for the program, the Ministry of Commerce (MOFCOM) is tasked with drawing up relevant regulations and supervising their implementation. MOFCOM entrusts the Quota Licensing Bureau (QLB) with the detailed oversight and inspection of all licenseissuing agencies nationwide (MOFCOM 2008). According to China's International Trade Law, the General Administration of Customs (GAC) and MOFCOM together compile, adjust and publish lists of goods that can only be exported after its previous and explicit approval. The International Trade Law also authorizes MOFCOM to investigate and punish companies, individuals and even government organizations that are violating its regulations, for example, by exporting without a license or outside the scope of the license or by issuing licenses to unqualified companies. Possible administrative sanctions include the suspension or revocation of a company's right to engage in foreign trade activities for up to three years, while individuals may face criminal charges.

In most cases, companies applying for export permits are required to submit an application form (stamped or sealed) together with a copy of the export contract and several other relevant pieces of documentation (depending on the nature of the product) for examination by an authorized licensing agency. The agency will then determine if the proposed export deal is in compliance with national rules and regulations, if all submitted documents are complete and valid and if the applicant company possesses sufficient management expertise to successfully carry out the transaction (MOFCOM 2008). Especially the final point invites a degree of arbitrariness into the process. Once granted, export licenses 
are valid for a period of up to six months, which may not begin prior to 1 January and will automatically expire at the end of the calendar year regardless of the time of issuance. Besides imposing time constraints on exporting enterprises, the licensing scheme can also force companies to declare export goods at one particular customs office or ship their total export volume in a single batch (MOFCOM 2008).

In May 2007, at a time of particularly fast export growth, MOFCOM and the GAC introduced an export licensing system concerning lowvalue-added steel products, such as rebar, wire rod, plates and narrow strip as well as several section products, while more advanced product categories like the majority of cold rolled sheet, galvanized products and all pipes were exempted (MOFCOM \& GAC 2007). This indicates that Chinese authorities aimed selectively at controlling-and if necessary curbing--low-end materials while leaving the more technology-intensive goods unaffected. The system included only a simple company registration process and did not involve elaborate application and examination procedures. At the time of introduction it covered product categories that had previously accounted for almost half of total export volume in steel products. By the end of 2008, when global market demand began to decline in the early phase of the global economic downturn, the export licensing system was terminated (China Mining 2009). While in operation, this system caused few distortions on market dynamics nor did it discriminate against specific companies on the grounds of size, ownership structure or other criteria. But not all export licensing schemes are as non-discriminate and transparent. The system could have evolved in a different direction if a reduction of export volumes would have come up on the agenda of China's administrators, as can be observed with respect to other Chinese export goods subjected to non-automatic licensing schemes. Practices employed here include specific eligibility threshold levels such as export performance, financial capabilities, as well as the filing of detailed application documents, bidding processes, etc. (USA 2010).

The administrative procedures introduced by non-automatic licensing are an important institutional foundation for the imposition and administration of export quotas on a variety of goods. China's International Trade Law designates MOFCOM as the agency responsible for administrating export quotas. As such, the ministry determines total quota amounts for different goods, evaluates individual quota applications and allocates quotas to specific companies (MOFTEC 2001; MOFCOM 2008). Though coke exports have been subjected to quotas 
for many years, only after they were cut by 25 per cent in 2004 has the issue attracted increased attention. But MOFCOM does not announce total annual export quotas for coke in advance. Instead, the ministry typically issues two notices a year that list approved companies with their respective quota allocations. Consequently, the total quota amount for one year can only be calculated ex-post by adding up the individual amounts as issued in the notices published during that year. For individual enterprises, this practice entails substantial planning insecurity and business risk.

The increasingly stringent requirements for obtaining quota allocations (MOFCOM various years) and the administrative hurdles complicating export transactions combined to bring down the number of approved coke exporters from 70 in 2006 to 34 for 2011 (with an additional 21 applications still pending in December 2010) (MOFCOM 2010). However, the total annual quota volume for coke has remained within a narrow range of 13 to 14 million metric tons since 2006, effectively boosting the individual quota allocations. It should be highlighted that approved coke exports account for only a small fraction of total Chinese coke output of about 350 million tons in 2009 and 2010.

Export restrictions on coke have led to irritations between China and other countries, such as the US, which have in the past procured substantial amounts of coke 'made in China'. The 2007 National Trade Estimate Report on Foreign Trade Barriers compiled by the United States Trade Representative (USTR 2007) shows that export restrictions have a significant adverse effect on US integrated steel producers and their customers, as China's tight export restrictions have pushed up export prices. In a series of meetings the United States urged China to eliminate the practice of using export restrictions, not just for coke but also for other products. In May 2005, the National Development and Reform Commission (NDRC) announced the cancellation of the coke export quota system as of 1 January 2006 (USTR 2007). But it was not meant to be. The decision was revised and the quota system stayed in place although with a raised quota of 14 million metric tons for 2006. Even today the export quota keeps international coke prices high and ensures that coke prices in China remain significantly below world market level. At the time of writing, the export quota system was still in force and there has been no indication of when it might be eliminated.

Chinese export duties take the form of ad valorem taxes levied upon exportation of certain goods. In some cases, like coke, duties are combined with export quotas to amplify the restricting effect. According 
to Chinese Regulations on Import and Export Duties, either shall be imposed on any good upon entering or leaving the country unless decided otherwise by the state council (State Council 2003). There are two government agencies trusted with administering import and export duties: the Customs Tariff Commission is mainly in charge of determining which goods are subjected to duties and adjusting relevant duty rates (State Council 2003). The GAC is tasked with the actual supervision and control of goods entering or leaving the country. As such, it collects duties as well as other charges related to goods crossing the border into or out of China. It should be noted that other raw materials used for steel-making, such as zinc, are affected as well (USA 2010).

As early as November 2006, the Chinese government imposed export duties of 5 per cent on coke. Duties were gradually raised to 15 per cent in June 2007, to 25 per cent in January 2008 and finally to the current level of 40 per cent in August 2008. Addressing the various steps, government authorities have argued that a rebound of coke exports had to be prevented. Considering that export volumes had been already capped by export quotas, as outlined above, the official line of argument is hard to follow. Price and Nance (2010), comparing the development of coke prices for domestic consumption and export, find that a large gap had formed between 2007 and 2008. While there was no price difference to speak of in January 2007, with one ton of coke for both domestic consumption and exports costing about US $\$ 150$, by December 2008 coke prices for domestic consumption had risen to about US $\$ 200$, while export quotations reached as high as US\$241. The resulting price difference conferred a discount of more than 50 per cent upon domestic coke users. Assuming an average input ratio of 0.6 tons of coke per ton of crude steel (World Coal Institute 2007), the benefit in input costs per ton of crude steel that could be claimed by Chinese steel-makers was US $\$ 400$. This is a very sizable advantage considering that in December 2008 the average sales price per ton of hot rolled sheet in the Chinese market stood at about US\$550. ${ }^{12}$ Figures 1 and 2 illustrate the effect of export restrictions on Chinese coke exports.

In 1994 China introduced a value added tax (VAT) that is levied on producers upon sales of nearly all goods and services. Rates vary depending on product category and amount, up to 17 per cent for steel products and most resources. While imported goods are subjected to the tax, exports are partially exempted. This is intended to avoid disadvantages for Chinese exporters competing on foreign markets that are not subject to VAT (HKTDC 2009). However, VAT exemptions for exports 
FIGURE 1: Production, Exports and Export Ratio of Coke

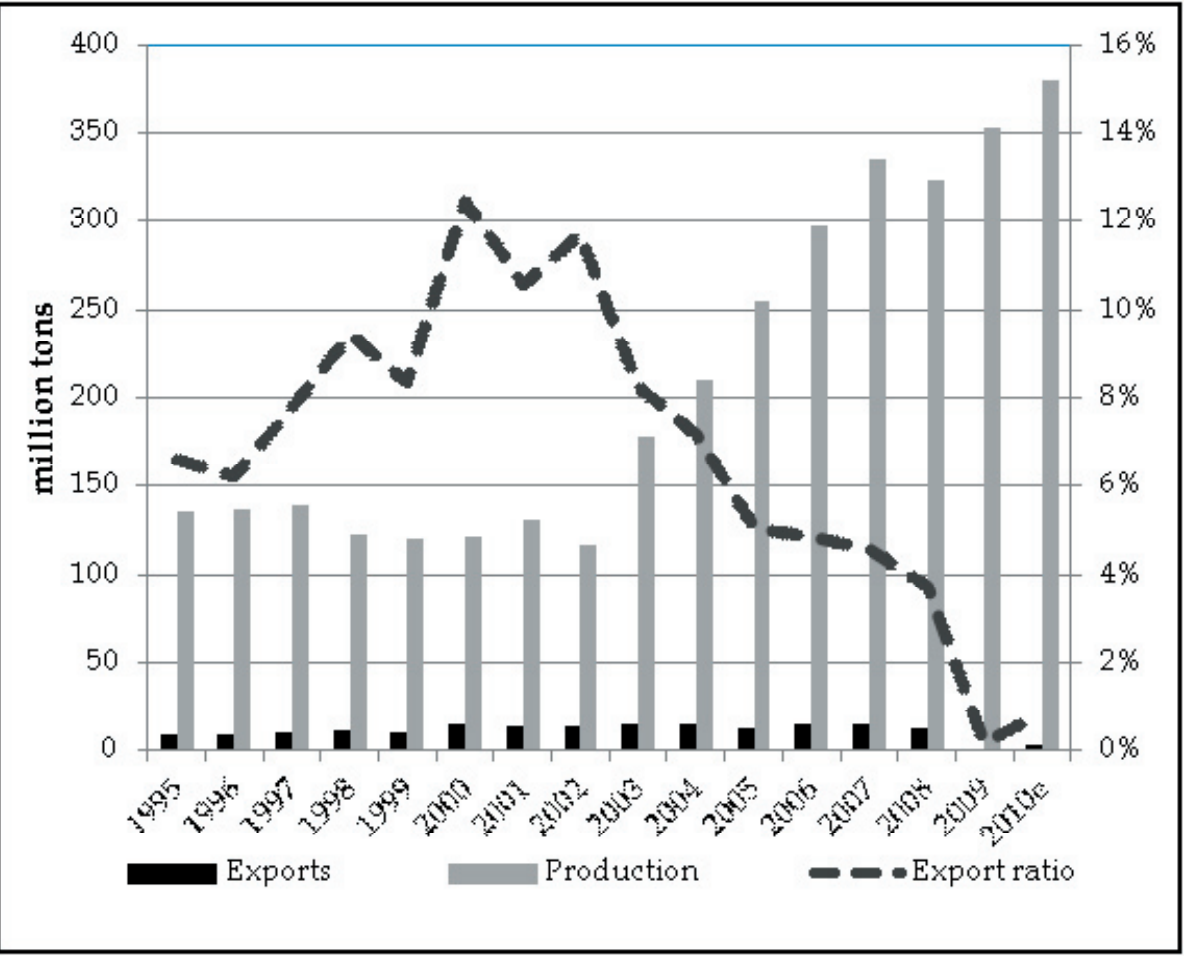

Source: CISA various years.

do not apply uniformly to all goods but are administered on a productspecific basis as a way to support Chinese industry policies. Following this logic, tax and customs authorities have gradually reduced or even cancelled VAT rebates to discourage export of certain goods (Ernst \& Young 2007). As a matter of fact, rebates for coke have been abolished. The same is true for semi-finished steel products such as billet and slab. This shift in trade policies has led to a sharp drop in export quantities (if export volumes were not already limited by quotas) and a domestic price level that is lower than it should be under normal circumstances. Limiting the outflows of billet and slab has two effects, which are in line with China's industrial policy framework for the steel industry. First, downstream production processes can benefit from cheaper access to an important input. Though large integrated steel mills usually do not purchase billet from the market but rely on the output of their own converters instead, many rolling mills that do not possess their own steel smelting capacities depend on the market availability of this semi-finished product. Thus, reduced price levels will eventually show a positive effect on the steel rolling and processing business. Second, 
Peter in der Heiden and Markus Taube

FIGURE 2: Chinese Coke Exports and Related Restrictions

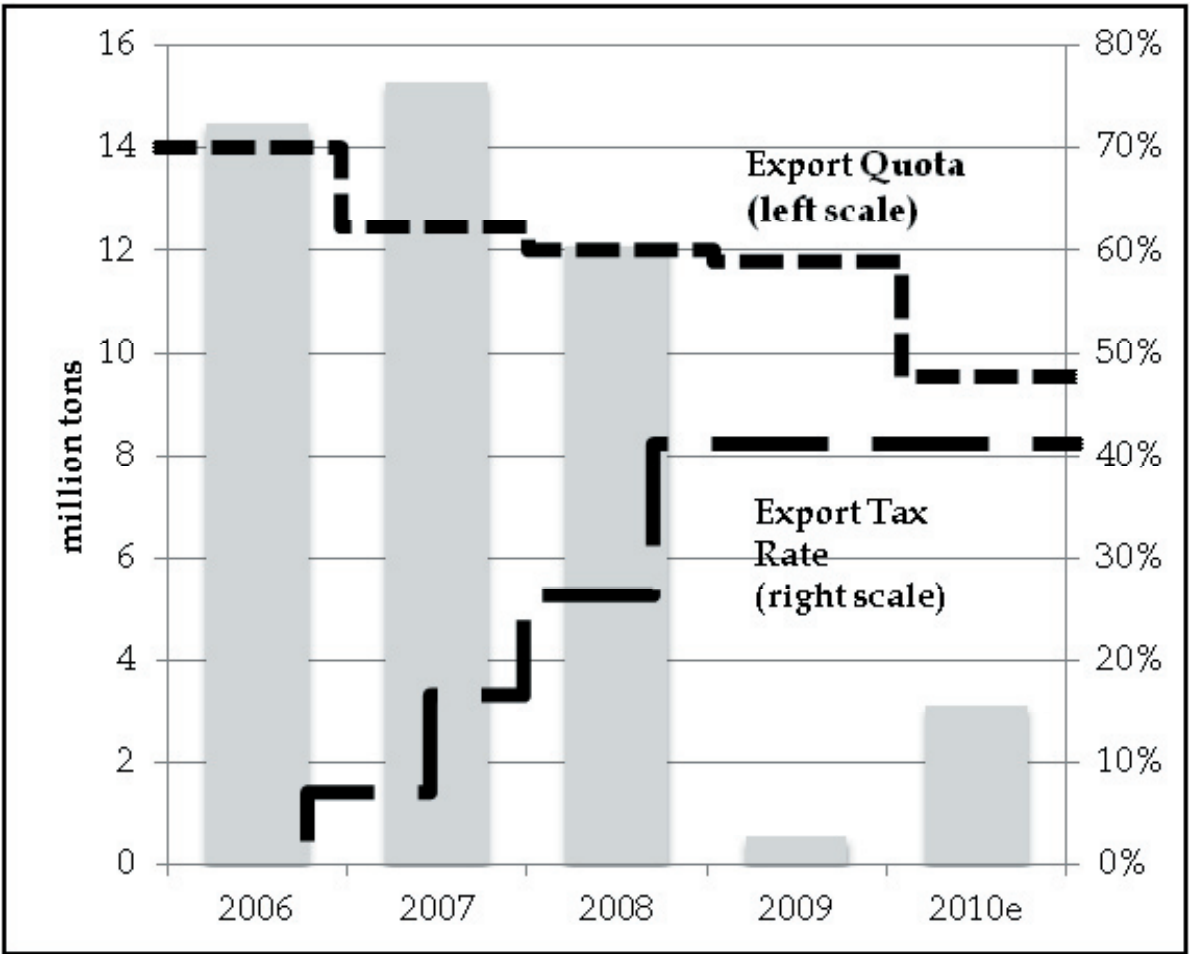

Source: CISA various years.

market potential and profitability of upstream producers is largely reduced, paving the way for industry consolidation. While basic steel smelting is a fairly low-value-added and low-tech activity compared to finishing processes downstream, it consumes large amounts of resources and energy and puts severe strain on the environment through pollution and greenhouse gas emissions. To remedy an industrial lay-out featuring a large number of small-scale enterprises employing basic production technology, the government actively supports industry consolidation characterized as the crystallization of a small number of large, integrated enterprises that possess strong technological capacities and international competitiveness. This approach specifically aims to crowd out small, inefficient players of the market (GOSC 2010; State Council 2010).

A similar development strategy as in the case of coke can also be observed with respect to billet and hot rolled (HR) strip. The latter is a fairly basic steel product that is commonly used as input for making more sophisticated goods. For rolling mills that produce cold rolled sheet (CR sheet), hot-dip galvanized sheet (HDG sheet), welded tubes and many other goods, HR strip is the single most important input-both 
in technical and in financial terms. In other words, the cost of making or buying HR sheet usually determines a mill's profitability.

In its 2007 Hot Rolled Sheet Reinvestigation Memorandum, the Canadian Border Services Agency (CBSA) came to the conclusion that domestic HR sheet prices in China are largely determined by the government and are not substantially the same as they would be if determined by a competitive market environment. The document cites various news clips and reports that point out the strong government intervention in the Chinese steel industry. The investigation identified instruments of government influence in the Chinese steel sector that have also been documented in the preceding sections of this article (CBSA 2007).

In the years preceding the world financial crisis, the Chinese government has resorted to VAT rebate adjustments in order to put an end to soaring exports of HR strip (and sheet). Step by step, rebates were cut from 11 per cent in 2006 to zero in April 2007. Government officials have explained that through imposing these measures, they wanted to better control production and exports, prevent more trade disputes, phase out inefficient capacities, cut down energy consumption and protect the environment. The diminished profitability of international sales effectively reduced the outflow of HR strip and increased supply in the domestic market entailing a price depressing effect (see Taube \& in der Heiden 2009).

When the shock waves caused by the global economic downturn reached China in 2009, the country's steel industry was under severe stress to cope with faltering demand and depressed prices. As a way to support ailing steel-makers, the central government opted for a reinstatement of export VAT rebates on HR products in the order of 9 per cent in June 2009. Consequently, exports rebounded since Chinesemade HR sheet regained competitiveness in major export markets such as South Korea. As China and the world economy gradually turned toward economic recovery, exports soared again, which inspired the government to once again terminate VAT rebates on HR strip in July 2010 (see Figure 3).

This brief history of adjustments illustrates that the Chinese government considers VAT rebates a legitimate and effective tool to steer exports in ways conducive to its industrial policy framework. This notion is supported by the fact that export restrictions did not target the more advanced downstream products like cold rolled sheet or galvanized sheet in the same way. Steel mills are still entitled to receive a VAT rebate of 9 per cent on exports of high-grade CR sheet and HDG sheet. 
FIGURE 3: Exports of Hot Rolled Strip and Related Export Restric-

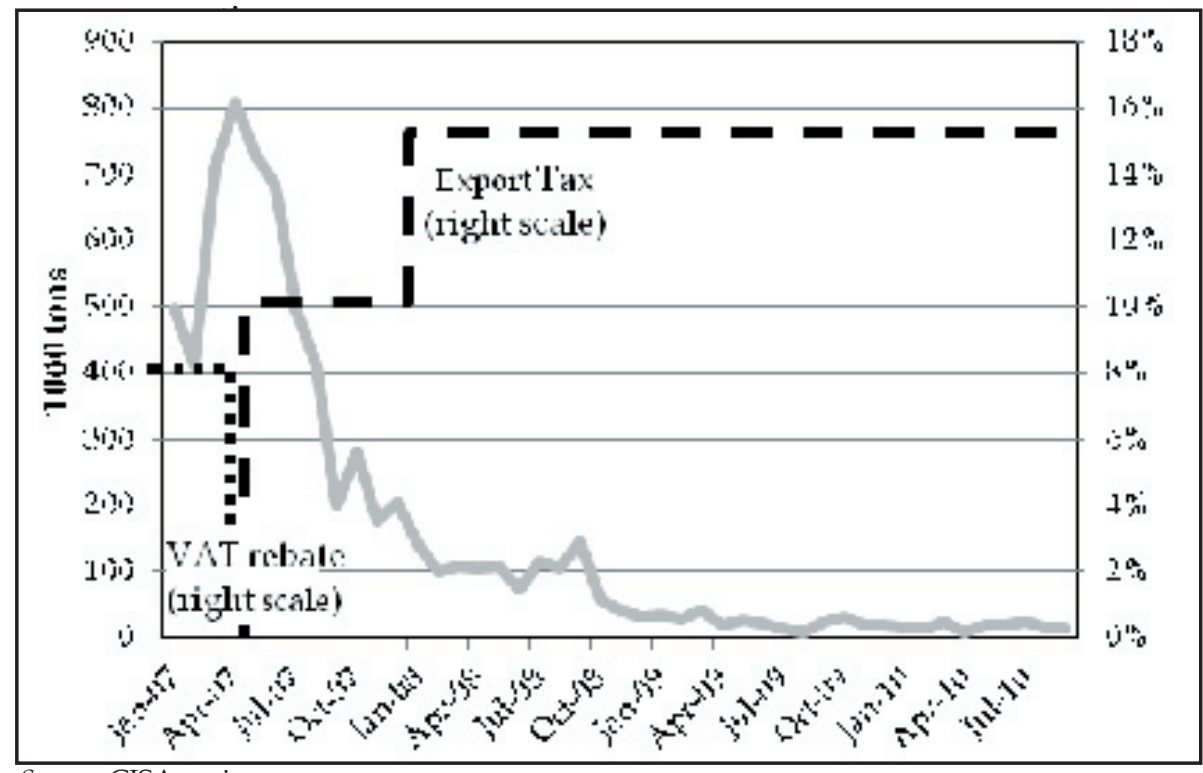

Source: CISA various years.

While the mechanisms described so far were mainly intended to curb exports, mandatory export price coordination - which can be equated to setting a minimum price for exports - also serves to maximize the gains from exports. Access to detailed information is complicated because relevant documents are not in the public domain. As a major difference compared to the other tools described earlier, the coordination of export prices is largely run by the China Chamber of Commerce of Metals, Minerals and Chemicals Importers and Exporters (CCCMC), a privately organized representative association of over 4,200 industry members. Founded in 1988, CCCMC originally served to coordinate export activities of Chinese companies and improve their competitiveness in world markets. Today the chamber defines itself as a comprehensive service provider to its members (CCCMC 2010). According to the self-introduction found on the CCCMC website, services include:

coordination service in metals, minerals, chemicals exports, coordination service in bidding commodities, organization service at the Chinese Export Commodities Fair, organizing response to anti-dumping lawsuits, verifying export prices for customs clearance, Internet information service, overseas exhibition \& training service (CCCMC 2010)

But CCCMC does not conform to the Western understanding of industry associations as being platforms to organize and represent private interests vis-à-vis government authorities (USA 2010). Instead, 
CCCMC - like other chambers of commerce in China-has assumed some regulatory power and responsibilities from state organs (in this case MOFCOM) to support the implementation of their industrial strategies and engage in active supervision. As such, CCCMC is under the authority of MOFCOM and acts on its behalf. Several sub-organizations are in charge of coordination activities regarding various commodities, such as coke and zinc (USA 2010). These units are authorized to audit member companies to assess their compliance with coordination programs and set penalties for violators.

\section{Exports of Finished Products}

Chinese steel exports have only picked up after China's WTO entry. Since 2006, it has remained a net-exporter of steel in volume terms. After a strong but unsteady rise in the years preceding the world economic crisis, export volumes topped off at 63 million tons in 2007 (WSA 2010). Exports are dominated by medium and lower product ranges with long products accounting for the largest share (EDRCMI various years). The Chinese government is promoting export activities on a highly selective basis, targeting high-value-added, technology-intensive products as the vanguard of China's steel exports. Specific measures include the rebate of a large part of the VAT paid. This is meant to offset competitive disadvantages in international markets ${ }^{13}$ and allows for a discretionary steering of export activities. These rebates may be coupled with income tax reductions if exports surpass 50 per cent of a company's total sales volume. Further measures comprise preferential export loans and guarantee schemes provided by the Export Import Bank of China (EXIM Bank) as well as other state-owned financial institutions (see Taube \& in der Heiden 2010 for details).

As outlined in the preceding section, VAT rebates and export quotas are employed by the Chinese government as highly flexible instruments for discretionarily steering corporate export activities. These measures are commonly used to promote exports of higher-value-added products and discourage exports of resource-intensive but low-tech products, such as rebar. If deemed necessary, for example, due to changing market conditions or escalating trade frictions, rebates and quotas can be adjusted on short notice in order to strengthen or weaken export incentives. This way, Chinese authorities are also capable of influencing the composition of steel exports and pushing companies to shift their export portfolio towards more highvalue-added, technology-intensive products. Figure 4 illustrates the effect of export restrictions on outflows of low-end products, such as rebar. 
Besides fiscal measures to manipulate export activities, directed bank lending also plays an important role (MIIT 2009). Some state-owned banks that have become shareholders of Chinese steel-makers through debt-to-equity swaps in the years preceding China's accession to the WTO also have a strong interest in supporting the steel industry in its efforts to get a foothold in the international markets (World Bank 2000; People's Daily Online 2000).

FIGURE 4: Exports of Rebar and Related Export Restrictions

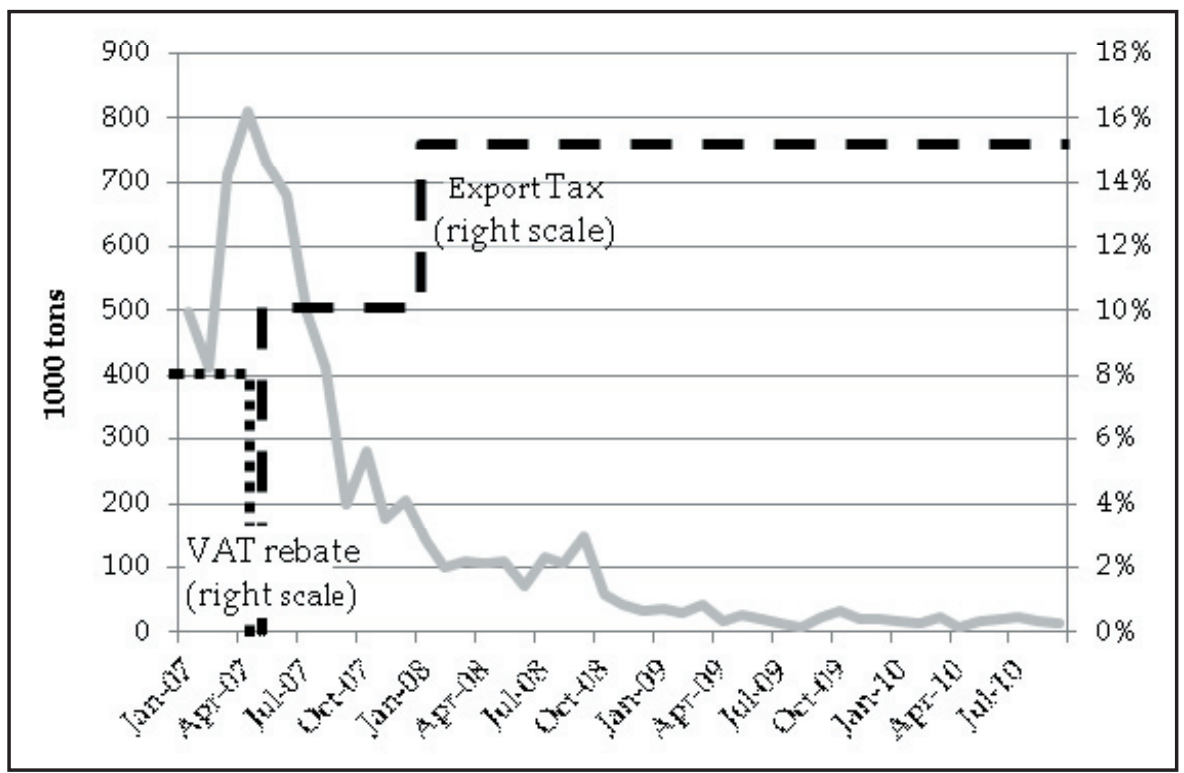

Source: CISA various years.

The EXIM Bank has been created as 'a state policy bank under the direct leadership of the State Council' with the mandate 'to implement the state policies in industry, foreign trade and economy and finance to provide policy financial support so as to promote exports [... and to] support Chinese companies with competitive advantages to "go global" for offshore construction contracts and overseas investment projects' (MOFCOM 2006). In 2004, for example, the bank signed a 'Cooperation Agreement of Export Credit Loans to Support International Business' with Baosteel, pledging RMB 10 billion in export credit loans with low interest rates and long-term maturity to help the enterprise develop internationalized business. ${ }^{14}$ Guangdong Shaogang Songshan Co., Ltd. in 2005 received interest discounts worth RMB 576,389 as a gratification for its successful export activities (Guangdong Shaogang Songshan Co., Ltd. 2005). 
Rapidly rising Chinese exports both before and after the world economic crisis have led to tensions with major trade partners, notably the European Union, the United States and Canada, but also a number of developing countries. After numerous studies and countervailing duty investigations have identified government subsidy schemes supporting Chinese steel-makers to compete in the global arena (see Taube \& in der Heiden 2009 for details), CISA and leading decision-making bodies in China's steel community are very much aware of the fact that the Chinese export offensive in the OECD economies of Europe, North America and South Korea is causing uneasiness in these countries and raises the 'danger' of trade measures against China designed to correct the non-market-based cost advantages of Chinese exporters. Luo Bingsheng, CISA executive vice president, for example, has been quoted by the Chinese news agency Xinhua as urging 'Chinese steel producers and dealers to curb exports at certain periods to avoid dumping charges'. ${ }^{15}$ This statement is but one example of how government authorities and CISA, as a kind of supervisory organization, signal domestic steel-makers the current political 'guiding opinion' towards certain aspects of global market integration and outline the range of 'politically correct behaviour'. Furthermore, such statements are often accompanied by actual policies directly intervening in the incentive systems determining the behaviour of exporters.

This section has illustrated that while economic policy-makers in China are determined to increase international integration of their domestic steel industry through trade, they reserve themselves the right to steer the depth and direction of this process. Clearly, Chinese enterprises are discouraged and sometimes forbidden to compete on the low end of the international market while for those who are able to target the high end, obstacles are few and far between. Political measures governing international trade integration are highly discretionary. By artificially depressing the domestic price of an important input resource, hot rolled sheet, and simultaneously offering export incentives for finished products, the authorities are effectively stimulating outflows of highvalue-added, high-tech steel goods like cold rolled sheet or hot-dipped galvanized sheet. ${ }^{16}$ As such, the Chinese government is distorting the inter-sectoral market structure as well as China's export composition. Seen from a macro-perspective, it is directly intervening in the 'natural' domestic as well as international market development. 


\section{Cross Border Investment in China's Iron and Steel Industry}

\section{Inward Foreign Direct Investment}

With respect to the treatment of foreign investors, the Chinese government is following a two-pronged strategy, trying to strike a balance between both the need to attract investors in order to get access to superior foreign technology, management skills and business models on the one hand, and the fear of a sell-out of national assets and foreign domination of the domestic steel industry - which is defined as a strategic pillar industry - on the other hand.

The Catalogue for the Guidance of Foreign Investment, which is updated at irregular intervals and provides for encouragement as well as restrictions for foreign investors depending on parameters such as product category, technology content, export orientation, etc., has been of specific importance for guiding foreign investment in China's steel industry, especially in its 1997 edition (NDRC and MOFCOM various years) $\cdot{ }^{17}$ Since then, the Catalogue has lost in importance for the steel industry and has been replaced by specific local regulations as well as the Iron and Steel Industry Development Policy (ISIDP) published in July 2005 (NDRC 2005).

With respect to the intention to attract technologically advanced investment projects, the ISIDP provides detailed information on technologies China wishes to attract as well as the ones that are discouraged. In addition, the ISIDP (Article 23) clarifies that only experienced enterprises with a formidable track record of successful business operations will be allowed to invest in China. In order to become eligible to apply for an investment project in China, foreign investors must:

possess iron and steel technology with independent intellectual property rights and should have produced at least 10 million tons of carbon steel or at least 1 million tons of high-alloyed special steel in the previous year (ISIDP, Article 23).

With these entrance requirements, the Chinese government openly discriminates against foreign investors who face tougher entrance barriers than domestic investors. Domestic investors who plan investment projects in the fields of iron-making, steel-making or steel-rolling need to fund 40 per cent of the total equity by themselves, meet all requirements laid out in various laws and regulations on environmental protection, ecology and production security, possess financial strength, 
advanced technological and managerial know-how and command a complete sales network. If a Chinese steel company wants to expand across administrative regions inside China it also needs to prove that it had owned capacities for smelting 5 million tons of carbon steel or 500,000 tons of special steel in the previous year. In any case, domestic investors are not required to possess their own technology. Moreover, for a foreign company, capacity thresholds are twice as high as for domestic companies.

At the same that China is courting (and sometimes prodding) foreign investors to transfer their latest technology to China and make it available to the local steel industry, China rejects the request of foreign investors to pursue wholly foreign-owned greenfield investments or to acquire majority or controlling stakes in Chinese steel enterprises. As such, foreign investors are forced to forge joint ventures with Chinese partners if they wish to enter the Chinese market.

All foreign investment activities (greenfield as well as merger and acquisitions (M\&A) transactions) must be approved by the NDRC, which consults CISA and the leading (local) steel enterprises in the course of the approval process. Leading representatives of CISA have made it crystal clear that they do not intend to grant foreign investors a dominant role in individual steel joint ventures (except for very specific reasons in peripheral business fields) and least of all in the Chinese steel industry as a whole. ${ }^{18}$ By restricting access of foreign investors to China's steel industry, the government is meddling with the market-based allocation of capital and productive resources. Competitive processes are inhibited and comparatively unproductive domestic players unduly promoted.

\section{Outward Foreign Direct Investment}

In 1997, the 15th National Party Congress for the first time clearly stated the need to 'encourage outward investments that can bring to bear the country's relative competitive advantage and to improve the utilization of [...] two markets and two resources' (NCCPC 1997). One year later, the second plenary session of the 15th Central Party Committee stipulated to 'support a group of strong and competitive state-owned enterprises to go abroad, mainly to Africa, Central Asia, Middle East, Central Europe, South America and other regions, in order to set up factories there' (NCCPC 1998). After 1999 witnessed a plethora of regulatory documents aimed at promoting outward investments and putting in place a basic institutional framework in the form 
of rules and regulations, the following year marked the birth of the so called 'Going Out' Strategy. First introduced in the 10th Five-Year Plan (2001-2005) it was carried over into the 11th Five-Year Programme (2006-2010) and is set not only to be continued but strengthened in the foreseeable future. The Proposal for the Formulation of the 12th Five-Year Programme (2011-2015), promulgated in October 2010 by the Central Commission of the Communist Party, stipulates to accelerate the implementation of the Going Out Strategy and guide companies to invest overseas.

Chinese authorities attach great importance to the Going Out Strategy and regard it as a way to expand the development potential of the Chinese economy because it helps to achieve four objectives: (1) improve the supply of required resources, (2) stimulate product exports, (3) foster Chinese multinationals and brands, and (4) diversify production locations and sales markets to ease trade frictions (GOSC 2006). Over the past ten years, most policy documents targeting the steel industry's development contain a reference to the Going Out Strategy and call upon enterprises to venture abroad. The Adjustment and Revitalization Program for the Iron and Steel Industry (ARPISI), released in March 2009 at the height of the world financial crisis by the MIIT (2009), for example, demands that 'companies seize opportunities and actively pursue the Going Global Strategy' (ARPISI, Article 2.5.5). The Chinese government's support for steel-makers' outward investments is threefold: (1) financial support, (2) administrative support and (3) informational and other support.

Financial support comes in different forms, such as preferential access to capital markets and bank credit from state-owned commercial or policy banks (ARPISI, Article 4.9). In some cases, companies can also benefit from low-cost loans. When Baosteel took over a 15 per cent interest in Aquila Resources, an Australian company investing in mineral deposits, in August 2009, the Chinese steel-maker agreed to help Aquila secure financing from Chinese financial institutions to help the development of its projects. ${ }^{19}$ In June 2010 it was reported that Aquila had reached an initial agreement with the China Development Bank (CDB), one of three Chinese policy banks, to develop iron ore and coking coal projects. This does not come as a surprise since Baosteel is one of the CDB's strategic partners. ${ }^{20}$

Cash grants are another way for government authorities to support overseas investments. Jiangsu Shagang for example, has received a subsidy of RMB 1.35 million for its iron ore project in Australia in 2005 mak- 
ing the company the largest recipient of such funds in Jiangsu Province in that year. The money was paid out to the Zhangjiagang City-based parent company via the local finance and budget offices. ${ }^{21}$

Key steel-makers can also apply for support from various government-sponsored assistance funds. The ARPISI urges companies to make full use of three separate special funds: the Fund for Mining Rights to Overseas Mineral Resources, the Fund for Economic and Technical Cooperation Overseas and the Fund for Reducing Risk in Prospecting of Overseas Mineral Deposits. Mining operations of key steel enterprises can be promoted in a variety of ways stretching from the prospecting and exploitation of foreign ore deposits to technical cooperation and acquisitions (ARPISI, Article 4.10).

Since 1998, the CDB has launched several large financial vehicles, such as the China Africa Development Fund (CADF), to support Chinese investment of all industries in certain regions. The CADF, established in 2007 with a registered capital of US\$ 1 billion and the CDB as its sole shareholder, 'aims to support Chinese companies to develop the cooperation with Africa and enter the African market'. It can be assumed that the fund will operate in line with current investment promotion policies since 'CDB has accumulated profound experience vis-à-vis investing in Africa through its "Going Global" initiative' (CADF 2010).

Besides subsidies and favourable conditions for credit financing, companies can also take advantage of special tax incentives. As recently as 2010, the State Administration of Taxation (SAT) (2010) promised to increase fiscal support and ease the tax burden for enterprises following the Going Out Strategy. Relevant measures were to favourably adjust and clarify guidelines for tax credits and export taxes. Furthermore, steps were announced to prevent double taxation for both corporate and personal income tax.

Administrative support involves the simplification of administrative procedures and the elimination of bureaucratic barriers that have delayed or crippled overseas investment projects in the past. As China began to rapidly build up foreign exchange reserves, a host of regulations restricting the use of foreign currency became increasingly obsolete and were finally abolished in 2006. In the same year, the General Office of the State Council (GOSC) (2006) listed institutional deficiencies as the most important obstacle to outward investments and promised the reduction or cancellation of certain registration and approval procedures. While this point appeared to be high up on the central government's agenda, surprisingly little headway has been made since then because three 
years later, the ARPISI again announced a streamlining of official project approval procedures and improvements of administrative proceedings in areas such as credit, foreign exchange, taxation, human resources and immigration (ARPISI, Article 4.10). However, even as late as 2010, the Development and Research Centre of the State Council (2010) still criticized the approval procedures for investors as too complicated, intransparent and time consuming. ${ }^{22}$

Informational and other kinds of support covers a wide range of services provided by government organizations inside and outside China. In 2003, MOFCOM established the Foreign Investment Promotion Centre and launched an online database to help Chinese companies obtain and exchange relevant information. Reports concerning investment opportunities, relevant laws and regulations, trade barriers and other issues in different countries are published as well. In addition, economic and trade sections of Chinese embassies and consulate offices offer counselling to Chinese companies, help facilitate investment projects, support public relations activities or use their political clout for the benefit of Chinese investors. SAT has promised to assist companies venturing abroad by clarifying regulations, improving related information services and pursuing double tax conventions with other countries. To reduce the risk for investors, MOFCOM has signed agreements on the protection of investments with many countries and the state-owned China Export and Credit Insurance Company provides investment insurance services particularly relevant for miners active in politically unstable African countries.

From a functional perspective, government support for overseas investments by Chinese steel-makers concentrates on three focal points: (1) mining operations, (2) global sales and customer service networks and (3) production facilities.

As pointed out earlier, the rapid development of the Chinese economy - characterized by massive urbanization and industrialization trends - has fuelled an even more rapid expansion of domestic steel production that has driven the once self-sufficient steel sector towards high levels of import dependence and steep price increases for raw materials. Although this environment should be incentive enough for Chinese steel-makers to engage in overseas mining investments, ${ }^{23}$ the government is exerting influence as well. Mei Xinyu, a research fellow at the MOFCOM Research Centre, was quoted in July 2010 as saying that political power is now playing a major role in purchasing overseas mineral assets (Mysteel 2010). The ISIDP demands an intensification 
of overseas investment and international cooperation in mining operations and calls for the establishment of supply bases for iron ore, chromium ore, manganese ore, nickel ore, scrap steel and other raw materials. Furthermore, it promises support for large key enterprises investing in the exploitation of overseas mineral deposits by way of M\&A, joint ventures or cooperation agreements with foreign counterparts or through direct purchases of mining rights (ISIDP, Article 30; ARPISI, Article 3.8). CISA echoes government calls for greater overseas investments of China's steel conglomerates, urging them to increase the share of directly controlled overseas iron ore resources to one-third and eventually 60 per cent of Chinese import demand. For the time being, Chinese companies control less than 20 per cent of China's total import tonnage by means of overseas direct investment stakes (Taube \& in der Heiden 2009).

A specific feature of government support is 'FDI plus official development assistance (ODA)' packages, which provide for a complementary set of business investments and infrastructure development. Such activities in recent years have been observed with increasing frequency in Latin America and Africa. With respect to steel industry interests, Mauritania as well as Brazil have come into the focus of this new approach.

Besides steel-makers, mining companies are also encouraged to venture abroad. In a research paper, the Development Research Centre of the State Council (2010) reflects on Chinalco's failed attempt to increase its stake in Australia's second largest iron ore miner, Rio Tinto. The deal was met by unexpected levels of resistance from existing shareholders as well as the Australian public and political circles. The authors suggest that Chinese mining companies, not steel-makers, should invest in overseas mineral deposits since they operate on the same step of the value chain as their investment target and do not simultaneously act as customers with an inherent interest to drive down sales prices, which would undermine company profits and harm the interests of other investors.

Like steel-makers, miners can also claim government support for overseas investments. Since 2000, MOFCOM has established special funds to support mining enterprises by reducing the financial risk involved in conducting preliminary works such as feasibility studies. According to Xinhua, state funding has facilitated a series of risky prospecting projects abroad. ${ }^{24}$ Furthermore, the GOSC (2006) suggested accommodating the needs of predominantly non-state mining companies with transparent ownership structure, successful business operations, strong competitive- 
ness, advanced corporate governance systems and an internationalized workforce in terms of access to foreign currency, credit volumes and insurance coverage.

All large Chinese steel conglomerates are actively pushing the development of global sales and customer service networks. Since major customers in the automotive, machinery and shipbuilding industries require close coordination and cooperation with their steel suppliers regarding product specifications and quality, maintaining a local presence in foreign markets is particularly important. Furthermore, as new entrants in most overseas markets, Chinese companies usually face tough competition from other international steel-makers with well established business connections. Subsequently, setting up their own offices becomes an essential success factor. The ARPISI is among the policy documents that address the need to set up international sales and service networks (ARPISI, Article 4.10).

The promotion of overseas production facilities is a relatively new approach that policy documents have not yet addressed in detail and only a very few steel-makers, such as Wuhan Steel, are undertaking serious steps to build up production facilities abroad (China Mining 2010). Many projects announced in the past were either postponed or abandoned, like the steel plant joint venture of Baosteel and Vale in Brazil. ${ }^{25}$ Encouraging mills to set up overseas production bases aims at reducing domestic consumption of energy and resources, limiting environmental damage and greenhouse gas emissions as well as easing the pressure on domestic (transportation) infrastructure. Jia Yinsong, an official with the MIIT, told reporters that 'Chinese enterprises should be aware of the significance of transforming from production exports to capacity exports', while a senior representative for CISA urges Chinese steelmakers to 'learn from the Japanese counterparts who followed automobile manufacturers abroad, providing [them] with matching steel products from their overseas mills'. ${ }^{26}$

The establishment of overseas production bases is also expected to reduce international trade frictions. Already in 2006, the GOSC (2006) announced support for enterprises from industries with relatively large production resources to set up overseas processing bases. ${ }^{27}$ One effect the paper highlights is that in this way, companies can diversify the place of origin of their manufactured products so they show up in trade statistics as exports from other countries - not China. Tianjin Pipe Group is a good example of a Chinese steel-maker whose investment location decision was influenced by foreign trade barriers. The company's 
American export business was strongly affected by the US Department of Commerce's decision to impose import duties of up to 99 per cent on its main product: seamless pipes. The company decided to set up shop inside the United States and invest US\$ 1 billion in a manufacturing plant for seamless pipes in Corpus Christi, Texas (Prasso 2010).

Overall, FDI has proved an important avenue for China as it has pursued closer integration with the world economy. With regard to the steel industry, Chinese government authorities did not launch an all-out opening trend but rather held a utilitarian stance. This was based on their long-term objective to upgrade production technology, improve product portfolio and optimize product quality for maximum competitiveness. While barriers limiting outflows have been lowered, for example, by access to financing, or eliminated, with access to foreign currency, for example, they stand tall with inflows. Regulation governing inward FDI continues to restrict access to foreign companies that both possess advanced technologies and are prepared to share those with local joint venture counterparts. This serves to maximize potential spillovers. At the same time, international players wanting to go it alone in China or set up production in the low or medium product range continue to be unwelcome. Furthermore, nine years into Chinese WTO membership, foreign companies still do not stand a chance of official approval for acquisitions of controlling stakes in local steel-makers.

\section{Conclusion}

Seen in perspective, the integration of China's steel industry into the global economy has been a major transition. The process itself, however, has been heavily influenced by the plans and ambitions successive generations of economic policy-makers have worked out for 'their' steel industry. As a strategically important - and militarily relevant-branch of industry, steel-making has attracted constant attention and was subject to tight regulation. Industrial policy measures at the global market interface have therefore evolved to comprise a large variety of measures and means, from taxes and tariffs to government-mandated bank loans and ODA, in order to discretionarily steer the intensity of global market integration. By acting as a gate-keeper controlling all inward- and outward-directed activities, the Chinese government has been trying to hold the market forces in check and gain maximum advantage for China, its iron and steel industry and the economy as a whole. In doing so, China's administrators have demonstrated a remarkable degree of 
undogmatic flexibility and goal orientation. As such, the integration of China's steel industry into the global division of labour remains a function determined by global market parameters as well as normative policies determined in China's top economic policy circles. And interestingly, seen from this perspective, China's integration into the global system does not present itself as a one-way street, leading towards ever greater integration into the global system. Rather, a vacillating pattern emerges, where phases of higher intensities of global market integration alternate with an increased decoupling from global developments.

Three major conclusions can be drawn with respect to the political intentions and composite effects of the various government interventions, interventions that have been shown to effectively alter the size and direction of trade and investment flows.

First, export restrictions for vital inputs and the promotions for highervalue-added products by Chinese authorities have an immediate and an intermediate effect. Firstly, they provide domestic steel-makers with access to a large supply of low-priced materials while inflicting scarcity and price rises on their foreign counterparts. The increased profit margin enjoyed by Chinese companies vis-à-vis international competitors frees up resources that can be invested in the expansion and modernization of domestic production. Secondly, they reduce the supply of Chinese steel-making inputs on world markets, causing prices to rise, which stimulates additional exports from other countries that would otherwise not have occurred. Since foreign countries faced with increased exports of raw materials may feel the pinch from lower availability and high prices, they could opt to institute their own export barriers. In theory, this could lead to a vicious circle with every steel-producing country seeking to protect its domestic resources from overseas customers and escalating scarcity of freely available materials.

Second, by limiting foreign investments into its raw material sector and the steel industry in particular, government authorities prevent overseas steel-makers from setting up shop in China and taking advantage of the same favourable conditions enjoyed by Chinese firms abroad. Furthermore, tight entry regulations ensure that only technologically strong international players can engage in joint venture companies targeting the high-tech, high-value-added segment. By exclusively attracting investments in selected areas with the potential of technology spillovers, the government is trying to maximize the value of foreign investments to the iron and steel industry as well as the economy as a whole. 
Third, since government moves to influence trade and investment patterns are mostly announced on short notice and are therefore hard to predict, long-term planning for companies is complicated and has to involve second-guessing. Since iron ore mining, coking production and steel-making are all capital-intensive industries with long gestation times, companies both in China and abroad are burdened with substantial risks to their business decisions.

By shedding light on the industrial policy guidelines and processes implemented by Chinese authorities to closely supervise and steer the globalization of the steel industry, this article has demonstrated the substantiality of state influence on global integration patterns. In this regard it serves to illustrate the impact on the operations of Chinese firms and, perhaps more importantly, to draw attention to the relevance of Chinese state intervention on the present and future development patterns of the international markets for steel and relevant resources. The intense regulation of foreign trade and investment in China is bound to determine to a large extent the operational parameters for steel-makers and processors around the globe.

Peter in der Heiden is research associate and doctoral candidate at East Asian Economic Studies/China at the University of Duisburg Essen. He specializes in industrial policy research with a focus on resource-based industries in China. Markus Taube is Professor at the University of Duisburg-Essen for East Asian Economic Studies /China. He is a founding partner with THINK!DESK China Research and Consulting and Co-Director of the Confucius Institute Metropolis Ruhr. His research interests include the formal and informal institutional arrangements underlying economic development, the state-business nexus as well as consumer behaviour in China. (markus.taube@uni-due.de)

\section{NOTES}

1 The dramatic cutbacks in most other countries around the world certainly contributed to this situation.

2 Crude steel exports topped off in 2007 at 63 million tons before falling back to 25 million tons in 2009 under the influence of the global economic crisis. In 2010, on the background of robust economic growth in China and spurred by the massive stimulus package as well as recovering export demand, crude steel output has recovered to 45 million tons. At the time of writing, it was not yet possible to calculate a global market share because reliable global output figures were not available.

3 In value terms.

4 In 2009, the US and Japan exported 21 per cent and 42 per cent respectively (World Steel Association 2010). 
5 Both figures are based on volumes. Adjusting for the generally low average FEcontent of Chinese ores of 30 per cent as compared to the $64+$ per cent averages for Australia and Brazil, the Chinese iron ore output share shrinks correspondingly. Still, China remains the world's largest, if only by a small margin (USGS 2010).

6 People's Daily Online 2010. China's Iron Ore Import Dependency Hits 69\% [online], 28 January. Available from: http:/ / english.people.com.cn/90001/90778/90860/68 81750.html (accessed 12 December 2010).

7 Fifty-two per cent of worldwide iron ore outputs were exported in 2009 (World Steel Association, 2010).

8 The price per ton increased roughly sixfold: from about US\$28 in 2000 to US\$174 in late 2010 (World Bank 2010 and Bloomberg Quotes [online]. Available from: http:/ / www.bloomberg.com (accessed 10 December 2010).

9 It has to be differentiated between coking coal, a bituminous kind of coal with a certain content of moisture, ash, sulfur and other components, and coke, the product of heating coking coal in batteries at temperatures over 1,000 degrees Celsius for up to 36 hours in order to drive off volatile contents.

10 Coke serves as a reducing agent for smelting iron in a blast furnace and is an essential ingredient for steel-making.

11 China's share of the global coke market subsequently plummeted to 7 per cent and 4 per cent in volume and value terms respectively.

12 Bloomberg Quotes [online]. Available from: http://www.bloomberg.com (accessed 10 December 2010).

13 As most nations grant a 100 per cent refund of VAT paid for goods that have been exported, Chinese producers are not entitled to full VAT refunds by the Chinese government and subsequently end up with a cost disadvantage vis-à-vis their foreign competitors.

14 'China Export-Import Bank's 10 billion Yuan credit loans to help the Baogang Group "Walking Out" ', International Finance News, 10 September 2004.

15 'Official calls for stricter control over foreign access to steel sector' [online], 2 August. Available from: http://news.xinhuanet.com/english/2006-08/02/content_4911048. $\mathrm{htm}$ (accessed 14 December).

16 Interestingly, Chinese government authorities are implementing a combination of product-specific, regional-specific and sometimes even company-specific measures, which sometimes appear to be redundant. However, given the realities of the Chinese iron and steel industry's set-up, this may be the only way to achieve the supreme objective of making the domestic steel sector internationally competitive.

17 The latest edition of the catalogue, in place since December 1, 2007, does not contain any specific references to steel industry-relevant investment fields.

18 'China CISA blocks Arcelor Mittal steel mill buy' (Reuters), as quoted in China Mining 25 December 2006.

19 'Australian gov't approves China's Baosteel investment of Aquila'. Xinhua, 30 October 2009.

20 'Aquila Resources says China Development Bank to aid coal, steel projects' [online], 20 June 2010. Available from: http:/ / www.bloomberg.com/news/2010-06-21/aquilaresources-says-china-development-bank-to-aid-coal-steel-projects.html (accessed 7 December 2010).

21 'China Jiangsu Offering Over 6 M RMB of Subsidies to Overseas Investors', Financial Times, 15 February 2006.

22 It states that while projects on average have to pass scrutiny by three government departments, state-owned enterprises and insurance firms face the toughest bureaucratic hurdles requiring consent from the most agencies. These may involve the State 
Administration for Foreign Exchange, the MOFCOM, the National Development and Reform Commission, the Ministry of Finance, the State-owned Assets Supervision and Administration Commission, the China Insurance Regulatory Commission, the China Banking Regulatory Commission, the China Securities Regulatory Commission or other industry-specific supervision and administration bodies.

23 Even more so since steel-makers located in coastal areas are particularly encouraged to source iron ore, coke as well as other important raw and auxiliary materials from the world market (ISIDP at 30).

24 Xinua, 14 December 2004.

25 'Tangled web of interests on Mt Gibson register' [online], The Australian, 25 September 2009. Available from: http:/ / www.theaustralian.com.au/business/mining-energy/ tangled-web-of-interests-on-mt-gibson-register/story-e6frg9df-1225779314773 (accessed 10 December 2010).

26 'Experts urge Chinese steelmakers to build plants abroad to avoid trade barriers' [online], Xinhua, 12 May 2010. Available from http://news.xinhuanet.com/english2010/china/2010-05/12/c_13288752.htm (accessed 14 December).

27 While the steel industry is not explicitly mentioned in this context, it is beyond doubt that the Chinese steel industry has relatively large production potential.

\section{REFERENCES}

Canadian Border Services Agency (CBSA) (2007). Memorandum on the initiation of a section 20 inquiry for purposes of re-investigation on certain hot rolled steel sheet. Cases 4214-8/AD1262 and 4218-12/CV94.

Central Committee of the Communist Party of China (2010). 'Zhiding shi er wu guihua de jianyi' [Proposal for Formulating the 12th Five Year Programme].

China Africa Development Fund (CADF) (ed.) (2010). Chairman's Message [online]. Available from: http://www.cadfund.com/en/Column.asp?ColumnId=13 (accessed 13 December 2010).

China Chamber of Commerce of Metals Minerals \& Chemicals Importers and Exports (CCCMC) (2010). Brief Introduction to CCCMC [online]. Available from: http://www.cccmc.org.cn/EnglishWeb/Company/CmcBrIntro.aspx (accessed 8 December 2010).

China Coal Resource Net (2010). Chinese coke industry facing overcapacity [online]. Available from: http://en.sxcoal.com/38852/DataShow.html, 27 September (accessed 12 December 2010).

China Iron and Steel Association (CISA) (2009a). 'Gangtie hangye jinkou tiekuangshi maoyi zhixu zilü gongyue' [Convention for Enhancing Self-discipline in the Iron and Steel Industry to Ensure an Orderly Iron Ore Import Trade].

China Iron and Steel Association (CISA) (2009b). 'Shan Shanghua: zai 2009 nian di jiu jie zhongguo gangtie yuancailiao guoji yantaohui shang de jianghua' [Shan Shanghua: Speech at the Ninth China International Steel Resources Conference], 20 October.

China Iron and Steel Association (CISA) (2010). 'Shan Shanghua: zai zhongguo gangtie gongye xiehui san jie ba ci changwu lishi (kuoda) huiyi shang de baogao' [Shan Shanghua: Speech at the Third (Extended) Conference of the Eighth Executive Board], 30 July.

China Iron and Steel Association (CISA) (various years). 'Zhongguo gangtie gongye nianjian' [China Steel Yearbook] Beijing: China Iron and Steel Association.

China Iron and Steel Association (CISA) and China Chamber of Commerce of Metals Minerals \& Chemicals Importers and Exports (CCCMC) (2010). '2010 nian tiekuangshi 
jinkou qiye zizhi biaozhun ji shenbao chengxu' [Approval standards and application procedures for iron ore importing enterprises 2010].

China Mining (2009). Chinese steel export prospects remain bleak in 2009 [online]. Available from: http://www.chinamining.org/News/2009-01-07/1231309576d20851. html (accessed 10 December 2010).

China Mining (2010). Brazil's EBX, China's Wuhan to Sign Steel Mill Deal Friday [online]. 15 April. Available from: http://www.chinamining.org/Investment/2010-0415/1271300439d35509.html (accessed 12 December 2010).

Development Research Centre of the State Council 2010. 'Zhongguo ying ruhe wanshan duiwai ziyuan touzi' [How should China improve overseas resource investments], Zhongguo Jingji Shibao [China Economic Times], 12 April.

Economic Development and Research Centre for the Metallurgical Industry (EDRCMI) (various years). China Steel Yearbook. Beijing: China Iron and Steel Association.

Ernst \& Young (ed.) (2007). China further reduces VAT refunds on export goods. In Tax Services, 20 June [online]. Available from http:/ / www.eycom.ch/ publications / items/china/customs_international_trade_20070620/ey_20070620_customs_international_trade.pdf (accessed 9 December 2010).

General Administration of Customs (GAC) (2010). '2009 nian woguo jiaotan chukouliang rui jin' [National Coke Exports Fell Sharply in 2009].

General Office of the State Council (GOSC) (2006). 'Geng hao de shishi "zou chu qu" zhanlüe' [Improve the Implementation of the 'Going Out' Strategy].

General Office of the State Council (GOSC) (2010). 'Guowuyuan bangongting Guanyu jin yi bu jiada jie neng jian pai li du jia kuai gangtie gongye jiegou tiaozheng de ruogan yijian' [Several opinions of the General Office of the State Council concerning the intensification of efforts at energy conservation and emission reduction and on the acceleration of structural adjustment of the iron and steel industry].

Guangdong Shaogang Songshan Co., Ltd. (ed.) (2005). Guangdong Shaogang Songshan Co., Ltd. Annual Report 2005.

Hexun.com (2010). 'tiekuangshi jinkou zizhi qiye jiang jianshao' [The number of approved iron ore importing enterprises is going to be reduced] [online], 4 August. Available from: http:/ / stock.hexun.com/2010-08-04/124470560.html (accessed 9 December 2010).

Hong Kong Trade Development Council (HKTDC) (2009). 'Export Rebate Increases \& Scheme of Tax Reduction by VAT Transformation'. Shippers Today, 31(6): 60-63.

International Monetary Fund (IMF) (ed.) (2010). People's Republic of China. 2010 Article IV Consultation. IMF Country Report No. 10/238. Washington DC.

Ministry of Commerce (MOFCOM) (various years). 'Jiaotan chukou pei'e shenbao tiaojian he shenbao chengxu' [Application requirements and procedures for coke export quotas].

Ministry of Commerce (MOFCOM) (2006). The Introduction of the Export-Import Bank of China [online]. Available from: http:/ / www.fdi.gov.cn/pub/FDI_EN/Economy/ Investment \%20Environment/Economic\%20System/Finance \%20\&\%20Foreign $\%$ 20Exchange/Policy\%20Bank/Export\%20\&\%20Import\%20Bank\%20of\%20China/ t20061122_66662.htm (accessed 8 December 2010).

Ministry of Commerce (MOFCOM) (2008). 'Huowu chukou xukezheng guanli banfa' [Measures for the administration of export licenses for goods].

Ministry of Commerce (MOFCOM) (2010). '2011 nian jiaotan chukou qiye wangshang gongshi mingdan' [List of companies approved for coke exports in 2011 published online].

Ministry of Commerce (MOFCOM) and General Administration of Customs (GAC) (2007). 'Shixing chukou xukezheng guanli de gangcai chanpin mulu' [Catalogue of steel 
products subject to export licensing administration].

Ministry of Foreign Trade and International Cooperation (MOFTEC) (2001). 'Chukou shangpin pei'e guanli banfa' [Measures for the administration of export quotas for goods].

Ministry of Industry and Information Technology (MIIT) (2009). 'Gangtie chanye tiaozheng he zhenxing guihua' [Adjustment and Revitalization Programme for the Iron and Steel Industry].

Ministry of Industry and Information Technology (MIIT) (2010). '2010 nian woguo yu chan cugang 6.2 yi dun weilai wu nian chong jiegou tiaozheng' [National Crude Steel Output is predicted to reach 620 million tons - Restart of Structural Adjustment in the Future Five Years], 13 December.

Ministry of Industry and Information Technology (MIIT) (2011). '2011 nian shangbannian gangtie hangye chixu dixiao yunxing zhuanxing shengji po zai meijie' [Operational efficiency of Chinese iron and steel industry remains at low levels during the first half of 2011- restructuring and upgrading imminent], 2 August.

Mysteel (2010). Analysis: China's New RMB Exchange Rate and Export Rebate Policies to Help Steel, 28 July.

National Congress of the Communist Party of China (NCCPC) (ed.) (1997). Final document of the first plenary session of the 15th National Congress.

National Congress of the Communist Party of China (NCCPC) (ed.) (1998). Final document of the second plenary session of the 15th National Congress.

National Development and Reform Commission (NDRC) and Ministry of Commerce (MOFCOM) (various years). Catalogue for the Guidance of Foreign Investment Industries.

National Development and Reform Commission (NDRC) 2005. 'Gangtie chanye fazhan zhengce' [Iron and Steel Industry Development Policy].

Office of the United States Trade Representative (USTR) (ed.) various years. National Trade Estimate Report on Foreign Trade Barriers. China.

People's Daily Online (2000). Goal of SOE reform achieved [online]. Available from: http://english.peopledaily.com.cn/english/200012/27/eng20001227_58958.html, 27 December [accessed 8 December 2010].

People's Republic of China (2000). 'Zhonghua renmin gongheguo guomin jingji he shehui fazhan di shi ge wunian jihua gangyao' [Outline of the 10th five-year plan for the economic and social development of the People's Republic of China].

People's Republic of China (2005). 'Zhonghua renmin gongheguo guomin jingji he shehui fazhan di shiyi ge wunian guihua gangyao' [Outline of the 11th five-year programme for the economic and social development of the People's Republic of China].

Prasso, S. (2010). The United States of ... China? [online]. CNNMoney.com. Available from: http://money.cnn.com/2010/07/21/news/international/china_investments_US.fortune/index.htm, 21 July [accessed 13 December 2010].

Price, A. and D. Nance (2010). 'Export Barriers and the Steel Industry', in OECD (ed.), The Economic Impact of Export Restrictions on Raw Materials. Paris: OECD Publishing.

State Administration of Taxation (SAT) (2010). 'Guanyu jinyibu zuohao "zou chu qu" qiye shuiwu fuwu yu guanli gongzuo de yijian' [Opinions Concerning the Further Improvement of Tax Collection Services and Administrative for Enterprises 'Going Out'].

State Council (2003). 'Zhonghua renmin gongheguo jinchukou guanshui tiaoli' [Regulations for Import and Export Duties of the People's Republic of China].

State Council (2010). 'Guowuyuan guanyu jin yi bu jiaqiang taotai luohou channeng gong$z$ uo de tongzhi' [Circular of the State Council concerning further strengthening the elimination of backward capacities].

Sun Zesheng and Xu Xingdong (2009). 'Empirical Study on Chinese Coke Export Market 
Power'. Journal of Chinese Economic and Foreign Trade Studies, 2(2).

Taube, Markus and Peter in der Heiden (2009). The state-business nexus in China's steel industry - Chinese Market Distortions in Domestic and International Perspective. Report compiled for the European Confederation of Iron and Steel Industries.

Taube, Markus and Peter in der Heiden (2010). China Steel Inc. - State-owned and state-run? An investigation of state-business interaction in the world's largest steel industry. Marburg: Metropolis-Verlag.

United Nations Conference on Trade and Development (UNCTAD) (ed.) (2010). World Investment Report 2010. Geneva.

United Nations Statistics Division (Comtrade) (ed.) (various years). The International Trade Statistics Yearbook. New York: The United Nations.

United States Geological Survey (USGS) (2010). Mineral Commodity Summaries 2009. Washington DC: United States Geological Service.

United States of America (USA) (2010). China - Measures Related to the Exportation of Various Raw Materials. First written submission to the WTO concerning dispute settlement cases DS394, DS395 and DS398. June 2010.

World Bank (2000). 'China gets ready for debt-equity swaps', in Beyond Transition, January/February.

World Bank (2010). Commodity Price Data. Washington DC: The World Bank.

World Coal Institute (ed.) (2007). Coal \& Steel. London: The World Coal Association.

World Steel Association (WSA) (ed.) (various years). World Steel Yearbook. Brussels: World Steel Association.

World Trade Organization (WTO) (ed.) (2010). International Trade Statistics 2010. Geneva: World Trade Organization.

Yu Hong and Yang Mu (2010). China's Steel Industry: An Update. EAI Background Brief No. 501. Sinapore: East Asian Institute. 